\title{
SOME INVESTIGATIONS ON BRUCELLA AND PSOROPTES MITES INFECTIONS AMONG BARKI SHEEP FLOCKS
}

\author{
A. A. Derbala* and Y. A. Gbazi**

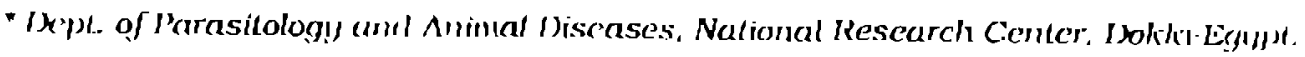

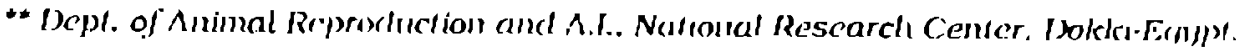

\begin{abstract}
Thoo graups of Barki eness in a private farm. aged 3-5 years, non-naccinaled achinist ..̈: brucella infection and had history of reproductive disturbances, iverc examined for brtcella infection by different serological te'sts. The first group (412 ewcs) has slin lesions. Mernmulike. the second gronp (375 euves) was clinically frec from skin lesions. Illext srmpless ucre taken from both gromps of etves (4 times within one year) for serodicumosis of brucella infection using tube agglutination lest (TAT), Rose Bengal plate tesi

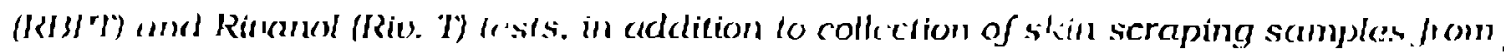

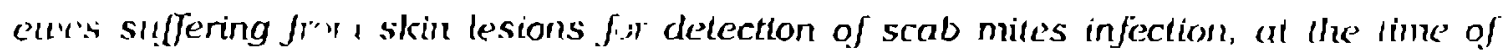
blonit sampling. The positite renctors of brucellosis by different serologicul lests urese recorded in both groups. It wess found atso inat"30.77\% of brucella positude enue's had psaroptes mites infection. The suguestrd role of mites in opening portals of brucella inf'ction lia skin was mintioned. Griner pigs used to assess this possible suggestive

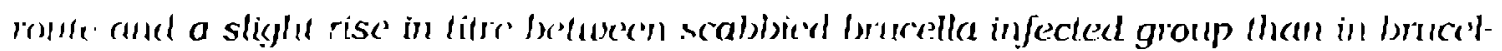

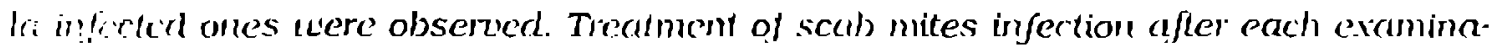
tion uns done using different specific drugs.
\end{abstract}

\section{INTRODUCTION}

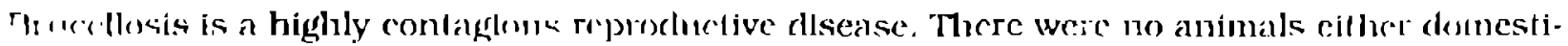

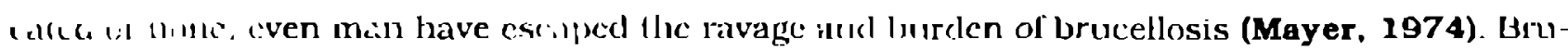
cella mlic lion causes abortion. weak bon lambs, cleally ol lambs, in addition lo mastitis in infer(all cwes (Fielden, 1986). Sheep brucellosis is usuatly caused by Brucclla melitcusis bul cer.esionally resulted from Brucella abortus Infectious. It is an acute or shronic disease characterizec! by septicalemia lollowed by leralization of infection in the lymph notes and genilal organs (Fyeden, 1986 and Marln et al., 1999). In Fgypt, brucellosis in shecp was invesiggalcd by sevcral aulik: s (Ismall, 1971; Shawkat, 1973; El-Bauomey, 1989). Mcanwlille. shecp) scal) is 


\section{A. A. Derbala and Y. A. Ghazi}

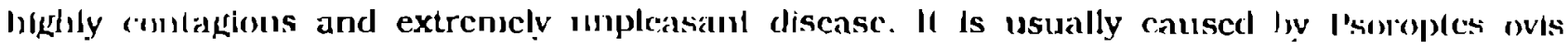
(hogg and Lohane, 1999). The miles live on the skin surlace and plerce lwe cpidermis to ficed on lymph ; ind serum exudates. Snsall pustules and hard ycllow crusis develop at the punclure sites (Asp and Taunl, 1988). There is ex(ensive loss of weighl galn. llecce and llle exposted skin is hickencel wilh raw patehes (Fattmah et al., 1994 and Nagal et al., 1995). The lesions observed are the result of combination of liaciors: damage caused by the nutte during kedinks. (he

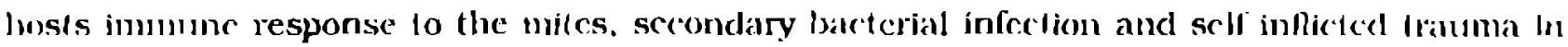
response 1o severe trrilation. wealsucss. Ioss of condition and death may ocew (Mahmond. 1960 and 13ill and Ilarry. 1984). In Esyjul. shecp milcs werc investigated by Ashmawy (1977). Viutlus studies were carred ont on the role of bacteria infection and its assoctatlon to shecp s(ab) miles Hogg and Lehane (1999) and Mahanta et al. (1997). Morcover. lew studies were curried oul on the role of blood sucking and biling insects (several kinds of theks and culex spp.) ats vertors of brueclia intection citber mechanically or biologically (Mayer, 1977) but no avaikable data about such relillon between shrep scals miles and brucella mlerobes transmisston were foumd. So Ilad, this sludy almed to Investigate the prevalence of brucellosis among seabbled slicep and the

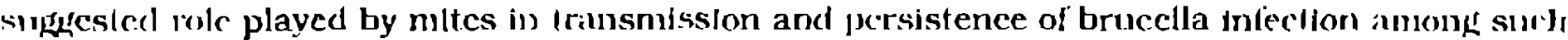
scolubecl lleiks.

\section{MATERLALS AND METHODS}

\section{Animals.}

Tivo groups ol Darki cwes in a privale farm. inged liom 3-5 years. non vacciniled algainst bru-

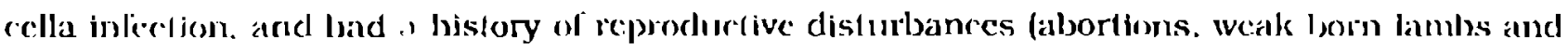

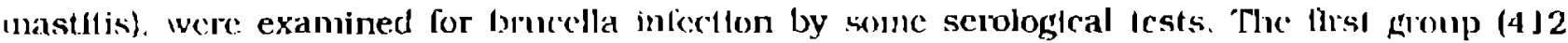
(wes) hakl skin lesions on cars. mose, mouth and neck that may be extenderl to tbe back ln some rwes. 'lhe aceourl group (375 cwes) ivas clinically free lirom skin lesions.

\section{Blood samples.}

I3lood sinples wete collecterl liom the examined ewes, four times within a year, ind sera were examined for scrodiagnosis of brucelia infectlon using tbe Tube Agglutinalion lest ('AnT). Rose Bengal platc (RBPT) and Rivanol (Riv. T) tests and the resulls were recorded als clescribed by Alton et al. (1988). The pos!luce rcaction was deterníncd at a titer of $\geq 1 / 40$ lor TAl. $\geq 1 / 20$ Ior IRIV. 'l' and agglutination reaction within one minute in RnPT.

\section{Skin examtnation.}

Skin lesions of suspected seabled ewes were moistened with glyecrine and scraped sinuples 


\section{A. A. Derbala and Y. A. Ghazi}

were collered in clean petr dishes all the lime of blool sampling. The samples were sulbjected to either direclly or after licaling not botling with 10\% potasslum hydroxide (Alkali maceralion

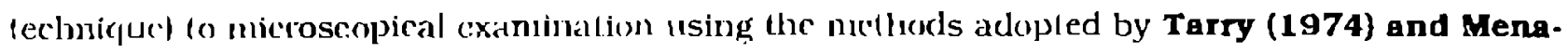
z1 (1976). 'line intes were identllicel iccorclink to Ashmawy (1977) and Blll and harry (1984).

\section{Bacteriologlcal examination.}

This was performed accordinfl lo Alton et al. (1988),

\section{- Culture of specimens :}

sample's of lymph nodes, genilal urgans. spleen were taken from slaughtered cwes which gave posltive scrolopical tests. These simples were cultured on brucella medium base (Oxold Co. USA) with brucella selcetive supplenent (each vial contains: Polymixin B. Barilrian. Cycloheximirle. Nalidixic acid, Nystatin and Vancomycin). This media prevent growtb of any bacteria or lungl rallher than brucella. These plates were incubated at $37^{\circ} \mathrm{C}$ under $5-10 \% \mathrm{CO}$ lension. periodically examined for suspected prowth alter 4 days and periodically examined lill aboul 35 days beforc discarded as negalive eulture. Suspected brucella eolony was confirmed by stainlng sincil's (Gram and Modifled Zlehl Neelsen stains).

Duting this investigation, all posilive ewes were segregated and slaughtered according to the test ancl slaughter progranume applied by ministry al" afgriculture. Egypt.

\section{Treatment :}

Moreover, all scabbed sheep were treated by injection will Ivomec (Merk \& Sharp 8 Dohme. NJ, USA) in a close of $1 \mathrm{ml} / 50 \mathrm{~kL}$ body weight at lìrsl cxamination. then by lecal $10 \% \mathrm{sulphur}$

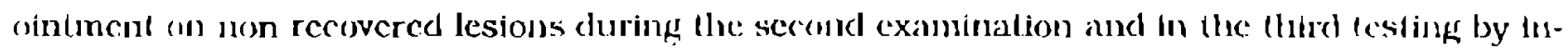
jection of Cicnesis (Abimeetln. Ancare NowZcaland LAcl. No. 247480) in a drise of $1 \mathrm{msl} / 50 \mathrm{~kg}$ bocly wcichlı.

\section{Experimental Infection of guinea plgs:}

An experinent was carricd ont on 15 funca plas in ceual three groups for charifyirng the pus(ibje ro!c of sluecp seab as an aid in lansmission of brueella infection. The lirst froufl was infecled by bollh positive sheep scaljies scraphng and Br. meltensls $16 \mathrm{M}$ strain in il plastic coll adherced and bandaged on the baek ol gurineal pigs.

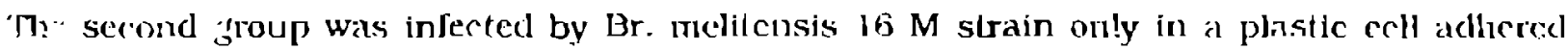
and handiced on the back of guinca pigs. The third group was served as control ikelative. The. rlinical manifestation were rcoreled and the guinea pigs groups were scarilicd after $f$ wecks and

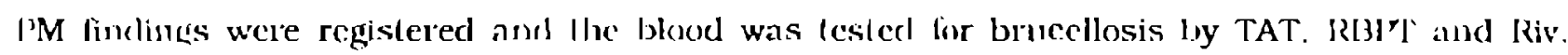
resis. 


\section{A. A. Derbala and Y. A. Ghazi}

\section{RESULTS \& DISCUSSION}

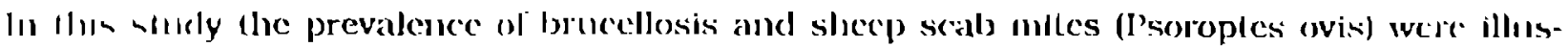
fralcel 11 I. I) le (1).

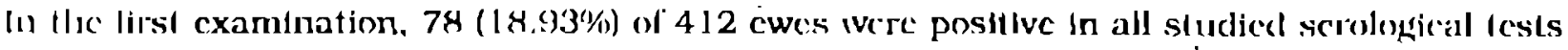
(or I) Iucellosis. whlle 134 (32.52\%) of them were posilive lor shcep scabs. In the second examinalion the: jerentages of hrucellosis and scabs in 3:34 cwes were $12.27 \%$ and In. $18 \%$ respectively. II lhe linicl eximination, the percentages werc $1.02 \%$ and $0.68 \%$ in bruecllosis and shcep scalss respcctively. While in the fourth examination werc $0.34 \%$ in bricellosis and ncyalive icsults in the shecp sialss. The number of cues had both inlections were 24 (5.8.3\%) in lluc first cxamlialion whilc ives 12 (3.59\%) In the sceond examinatlon. However. In the third and fourth cxamlnalions were movitive results.

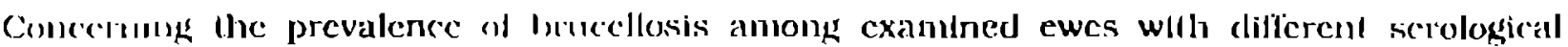

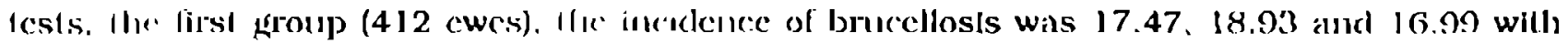

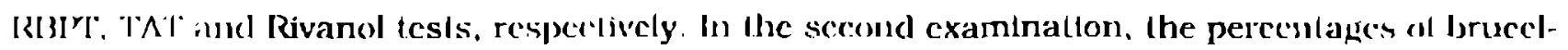
la inlection were 11.37, 12.27 and I 1.67 ivith RI31YT. TAT and RIvanol Lesis, respecthecly. In the

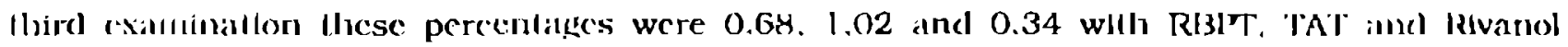
Icsis. respectively. The fourth examination showed only one positlve case with $T$ AT $(0.34 \%)$. Conreming sceond group (375 cwes). Ihe incidence of bricellosis was $5.06 \% .5 .86 \%$ and $4.8 \%$ with lरBIT, TAl and Rivanol lests in lle lirsl cxälninalionl.

The second examlnation was 0.84 .1 .13 and 0.84 with RBPT. "TAT and Rivinol lesls, respeclively. Meanwhile, it was $0.28,0.57$ ind $0.28 \%$ colth IRI3IT. TAT and Rivanol respectively. On 1 The

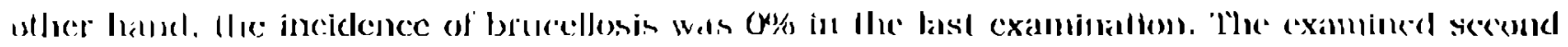
Hroup al cives poved to be negative lo Psoroples ovis infection during this study. Coneeruing the bacheriolngual examinations, lolal ummber of 123 slauglitered cwes durlng this stucly. which proverl brucelli posilive lests, was subjecicd to bactcrlological studies. The samples limm lymph nodes. emital organs and splecn were cullumed. Only two Isolates of I3rixcella spp. were ubtalned from lymplo andes and uterus ol infected ewes.

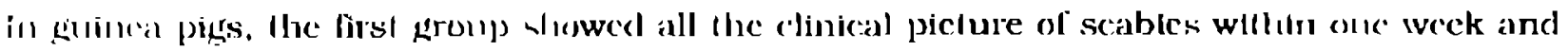
the blood scra showed positlve icsult for brucellosis. The cllnical symptoms of scalls in guinea pists were rleveloped as pastules al the silc of Inlcetton. whlch ruptured and lornicel yellow lonsts. swere irrltation and skin was lhickened and damaged. Moreover, elyling and scll-inflicted I ramma in response to severe irrilation was notleed ilong the pertod of study. The skin lesion was spread incl extended over lle back. abdomen, legs. ears and nose ol gulnea plgs.

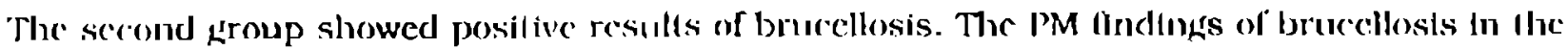




\section{A. A. Derbala and Y. A. Ghazi}

lirst and sccond groups were orchitis, cularged lymph nodes, liver and splecn. The cont rol group were nekillive for brurellosis and psoroptes mites infectlon.

Differci)t serodlagnostlc tesls including l(tbe agglutination. Rose Rengal platc and Rlvanol lests were perlormed lur dlagnosis of brucellosis arrong sheep.

In the present study, the prevalence of brucella infectlon, in the first gronp, by the studied scrologlcil lesis. declined from $18.93 \%$ to $12.28 \%$ then $101.02 \%$ and finally $0.34 \%$ : in the Hrst, second alsd thlrd examinations and revealed negalive result In the fourth examitualion. Ilowever. llic scroposillve incidences of brucclla infiction, in the sccond group. were 5.87\%, 1.13\%, 0.57\% and $O \%$ in the first, second, third and fourth exarninations respectlvely.

The dectine in the incidence of brucella postlive reactors in our study resulted firon the application of the periodical testing. slaughtering of positive animals, in addirion to the application of the hysjichic neasures according to the rules for control of brucellosis. Ministiy of Agrkeulture. lisypt.

In Lisjpt. the incidence of bruccllosis was ranged from 2.68\% to 18.5\% (Ismall. 1971: Shawkat, 1973 and El-Baupmey, 1989). The varlations hetween our results and those oblitined by ofher authors might be attribuled to breel, sex. ange locality. marngement and the slinge of infection, in aclition to the phys!nlogicial and immtune status of animals (Tizard, 1987; Nada, 1990; Nada et al., 1992 and Ghazy et al. . 2000!

The incidence of shcep scabies in (lic wesent study also declined from $32.52 \%$ to $0.68 \%$ along the fom cxininations. la this respect soll et al. (1992) reported an incidence valied from $0.4 \%$

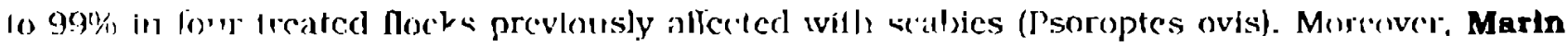

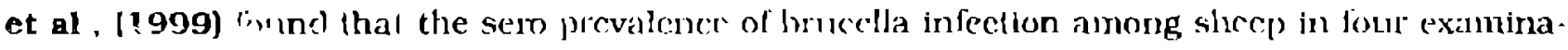
linic acte $80.9 \%, 2770 \%, 66.7 \%$ and $78.5 \%$

The clitical symptoms and the pressence of Psomptes ovis miles in the current sturly tvas simlats to linclings of Mabmoud (1960), Bill and Harry (1984) and Hogg and Lohene (1999).

Delection of Psoroptes ovis mites infection in 30.77\% of the brucella seroposilive cives in the fis st and in 29.27\% in the second examinations. payed the attention to suggest a probalble relalon belween both infections. In llils respect. various shdies mentioned by Mayer (1977) clescribed the role of insects (severa! kidels of ticks, culex spp. and fltes) as transmilters lor lirucella microbcs elther merhanleally or biolngically to the animals.

Cotton et al. (í: 3), Cotton (1934), Corbel (1989), Refai and Kopec (1989) and Alton (1990) indicaled the significant resce of skin as portal for entry of brucella organisms to animal body. In wur duvestigation the nitles might play a sole in the entry of brucella microongantsm 


\section{A. A. Derbala and Y. A. Ghazi}

through the brokened skin and increasing the Incidence of brucella infeetton among the frst Lroup in compartson to results of second group. In additlon, the scables had an immonosuppressive cllect on the host that might increase the susceptibllity of the animal to bricella Infect1on (Tizard, 1987).

It wiss noticed that a considerahle percentages of both Infectlons were present in lice second cxamination in spite of application of control measures following Rrst examination. Such finding may be due to the presence of various slages of infection and latency. The results of the gulnea pig experimental groups showed the appearance of clinical leslons of inites scab in the flrst group lion the ist to the 6th wcck which is similar io finding of Wilson et al. (1977). Meanwhlle. the second group showed slight decrease in degrces of reaclion of brucella antibodies than in the lirst group using the serological tests. lhis result coordinates with findings of Cotton et al. (1934), who statcd that brucclla inlection could be (ransmilted through broken, aljraded and cven a beillhy skin of anlinals.

In coullusion. the Psoroptes ovis iniles in shicep llock can aflect the prevalence of bruccllosis among tlic:m. So that in eontrol programmes of bruccllosis in sheep, the control of psoroptes mites mincellon must be taken in consicteration and the scabbled cases should subjectrd to lsolation. trealumcul and examination for brucellosis bclorc readditlon to the flock.

\section{Acknowledgerment}

Special sincere appreclation and gratefisl acknowledgement is made to the soul of Dr. A.R. Nada. Dept. of Reproduction and A.l. Nattonal Rescarch Center for his thoughtful. Inelpful and continuous support throughout this sturly. 
Table (1). The prevalence of bncella and psoroptes mites infections among examined Barki ewes.

\begin{tabular}{|c|c|c|c|c|c|c|c|c|c|}
\hline \multirow{2}{*}{$\begin{array}{c}\text { Examined } \\
\text { groups }\end{array}$} & \multirow{2}{*}{$\begin{array}{c}\text { Fint grisup of } \\
\text { eses }\end{array}$} & \multicolumn{2}{|c|}{ Bracella posisive enes } & \multicolumn{2}{|c|}{ Psomples mules infecred thes } & \multicolumn{2}{|c|}{ Ewes had bocth infections } & \multicolumn{2}{|c|}{$\begin{array}{l}\text { Ewes had both infectrons/iotal } \\
\text { seropositive ewes }\end{array}$} \\
\hline & & No. & Percentage \% & $\mathrm{Nn}$, & Percentage \% & No. & Percentage \% & No. & Percentare \% \\
\hline First exam & 412 & 78 & 1893 & tit & 3252 & 24 & 5.83 & $24 / 78$ & 3037 \\
\hline Second exam. & 334 & 41 & 12.28 & 34 & 10.18 & 12 & 3.59 & $i 2 / 4 i$ & 29.27 \\
\hline Thetd exam & 293 & 3 & 1.02 & 2 & 068 & - & - & & \\
\hline Fourth exan. & $290^{\circ}$ & $I$ & $\overline{0.34}$ & $=$ & - & - & - & & \\
\hline
\end{tabular}

Table (2). The prevalence of brucellosis among examined Barki ewes with different serological tests.

\begin{tabular}{|c|c|c|c|c|c|c|c|c|c|c|c|c|c|c|c|c|c|c|c|}
\hline \multirow{2}{*}{$\begin{array}{l}\text { Examunes } \\
\text { groups }\end{array}$} & \multicolumn{6}{|c|}{$1^{4}$ examination } & \multicolumn{5}{|c|}{$2^{\text {nd }}$ examination } & \multicolumn{5}{|c|}{$\overline{3}^{\text {Id }}$ sxanlinationl } & \multicolumn{3}{|c|}{$f^{\text {th }}$ examination } \\
\hline & $\overline{N_{0}}$ & $\%$ & No & 0 & $N_{0}$ & $\because$ & No & $\%$ & No $\overline{y_{0}}$ & Nio & $\%$ & $\overline{N_{0}}$ & $\%$ & $N_{0} \quad a_{0}$ & No & $\%$ & No $\%$ & $\sqrt{N_{3}} \%$ & No $0_{0}$ \\
\hline $\begin{array}{l}\text { First } \\
\text { troup }\end{array}$ & 72 & $17+3$ & 78 & 18.93 & 70 & 16.99 & 38 & 1137 & 1227 & 39 & 1167 & 2 & 0.68 & 1.02 & 1 & 034 & - & 0.34 & - \\
\hline $\begin{array}{l}\text { Tolai } \\
\text { number }\end{array}$ & \multicolumn{6}{|c|}{112} & \multicolumn{5}{|c|}{334} & \multicolumn{5}{|c|}{293} & \multicolumn{3}{|c|}{290} \\
\hline $\begin{array}{l}\text { Second } \\
\text { group }\end{array}$ & $\beta$ & 5.90 & 21 & 586 & 18 & +.8 & 3 & 084 & 1013 & 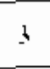 & 6et & 1 & 0.28 & 0.57 & 1 & 928 & - & - & - \\
\hline
\end{tabular}

* The variation of the number of examined ewes was due to the application of est and slaughter program of brucellosis. RBPT $=$ Rose Bengal plate test. 


\section{REFERENCES}

Alton, G. G. (1990) : Brucella inclilensis. 1887-1987. Anlmal Brucellosis. A. book. cl. K. Neilsen and J.R. Duncan. CIRC press. Bosion.

Alton, G. G.; Jones. L. M.; Angue, R. D. and Verger, J. M. (1988) : Tcchnlques for lie Brucellusis Laboratory. IINIRA. L'irls. ISUN. 1988.

Ashmawy. K. I. M. (1977) : Soule sturlics on the mites Infectlng sheep In Sharkla Governorate. M. V. Scl. Thesis. liac. Vet. Med.. Zagazig Unlv.

Asp. J. and Taunt, M. (1888) : Skin discases of Ethlopian sheep and their eflect on the pickled sikin. A minor Reld study. Working paper. Swedish Universtty of Agriculure Science Int. Riual Development Center. 1988. 189): 30.

Bil, A. and Harry, B. (1984) : Paristlic skln diseases of sheep. In practlce. Jan.. 1984: 4-8.

Corbel, M. J. (1989) : Brucellosis: Epidemiology and prevalence worldwide. Brucellosis: Clinical and laboratory aspects. $\Lambda$ hook cd. EJ Young and MJ Corbel. CRC press. Boston.

Cotton. W. E. (1934) : New researches and developments on enntagious abortlon bang s discisc. Proc. 121h Inter. Vel. Congr., 283-297.

Cotton. W. E.: Buck, J. M. and Smith, H. E. (1933) : Studles of the skin as is porlal of entry lior 13r. Abortus in pregnant cattle. JAVMA. 83: 91-100.

El-Bauomey, E. E. (1989) : Some sludies on hrucellosis in sheep and goats. M.V.Se, lhesis. Fac. VCL. Med., Cairo univ.

Fatimah. C. T.; Hassuzana, K.; Amin-Babjee, S. M.: Saharce, A. A. and Sharifah. S. H. (1994) : Skin conditions in shecp around scidang. M alaysia. J. Velcrinar Malaysla. $6: 37.41$.

Fielden. E. D. (1986) : Infectlous ovine abortion. In Morrow D. A., Ed : Current therapy In thertogsencology. 2- Diagnostic.treatment and prevention of reproductive diseases in small and large animals.W.B.Salunders Co. Phlladelphla. U.S.A., Pp:852-85737-41.

Ghazy, A. A.: Ghazt, Y. A. and Effat, M. A. (2000) : Soine studics on biuccllosis anumg Arab!an and thoroughbred horses In Egypt. J. Egypt. Vet. Med. Ass., 60: 45-65.

Hogg. J. C. and Lehane. M. J. (1999) : Iclentification of bacterlal species assoclated with sheep sı:ab mite (Psoroptes ovls) hy using amplified genes coding for 16 sr RNA. Appl. Envlron. Microblal., 65 : 4227-4229.

Ismall, E. M. (1971) : Studles on artlficial infection of Barkl sheep with Br. melltensis "Its dlag- 
nosls and effects on the reproductlve organs". M. D. Vel., thesls, Far. Vet. Meel., Cairo Iniv.

Mahanta, P. N., Thungchamo, K.: Dutta. G. N. and Devrlese, L. A. (1997) : Idenililialion and characterization of staplylococed isolated from eutaneous lesiọns of goals.J. of Vol.Mcd..44(5):309-311.

Mahmoud. M. A. (1960) : Public health importance of common animal cctoparastles. Thesis, Iligh Insilt. Pub. Hith., Nlex. Esypt.

Marln. C. M.; Moreno, E.: Moriyon, 1.; Dlaz. R. and Blasco, J. M. (1999) : Pcrformance of competitive and Indirect curyne linked immunosorbent assay, gel Inmunoprecipltation with native hapten polysarcharidc. and slandard serological lesis In diagnosis of' shcep bruccllosis. Clin. Diag. Laib. Immunol. 6: 269-272.

Mayer. M. E. (1974) : Advances in rescarch on bricellosis 1957-1972. Adv. Vet. Sti. Comp. Med.. 18: 231-250.

Mayer, M. E. (1977) : Epldemlolosical odds and ends. In "Bovine Brucellosis". An Int. Symp. Ed. I3v Creiwford, R.P. and Hitclalgo. R.J.

Menazi. A. M. M. (1976) : Some studics on diagnosis.caluses and treatment of mange in camIes.M.V.Sci.Thesis. Fac.Vet.Med.,Zagazlg Univ.

Nagal, K. B.: Katoch. R. C.: Mandeep-Sharma; Rao. v. N.; Mittra. S.; Sambyal, D. S. and Sharma, M. (1995) : An oulbreak of dermatophilosis In Gaddl sheep. Indian Vel. J., 72 : $1015 \cdot 1018$.

Nads. A. R. (1990) ; Further stuclies on brucellosis in camels. Ph. D., Thesis. Fat. Vel. Mcd., (Gitiso Univ.

Nada: A. R.; Shalaby, S. I. A. and Ahmed, W. M. (1992) : Minerals and Iracc clements, blood pronle of brucella Infected pregnant and non pregnant animals. Esypt. J. Comp. Pathol. Clin. I'athol.. 5: 203-213.

Refal, M. K. and Kopec, J. D. (1988) : A gulde to biriccllosis In cattle causcd by [3rucella abor- ' irs.Gineral Organization of Vel.Services. Dokkl.Lgypt.

Shamkat. E. (1973) : Studics on brucellosis in sheep and goats in Egypl. M.D. Vet.. Thcsls. laac. Vel. Med., Cairo Univ.

Solt, M. D.: Carmiehael. I. H.; Swan, G. E. and Abrey, A. (1992) : Treatment and control of slicep scals (Psoroptes ovls) will ivernectln under field conditlons in South Africa. Vet. Rec., 130: 572-574. 


\section{A. A. Derbala and Y. A. Ghazi}

Tarry, T. W. (1974) : Sheep stal): Ils diagnosis and biology. Vet. Rec.. 95: 530-532.

Tzard. I. R. (1987) : Veterlnary Immunolegy: An Introduction. 3rd cd.. W.B. Sinmders Co.. Philadelphia, USA, p.. 233-249.

Wilson, G. I.; Blechut, K. and Roberts, I. H. (1977) : The Infccllvity of scables (mangc) miles P'siroptes ovls. Acarina :I'soroplldac) to sheep in naturally contaminated cuclosures. Ress. Vct. Sc1., 22:292-297. 


$$
\begin{aligned}
& \text { اللحتص العريى } \\
& \text { بعض الاستيفاحات على مـرض البروسـيلا والإمسابـة بعلم البهـرب } \\
& \text { فى تطـعــان الأغــــــام الـبرقسى }
\end{aligned}
$$

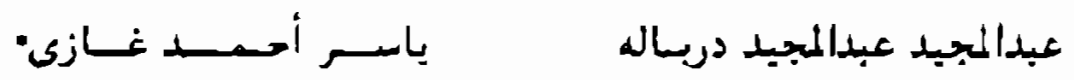

$$
\begin{aligned}
& \text { تسم الطفيليات رأمراض الحيران - تسم الـكانر الميرانى رالـلتيع الهـناعن" } \\
& \text { المركز الترمى للبعرث - الدفى - جيزة - جسهورية معر العريية }
\end{aligned}
$$

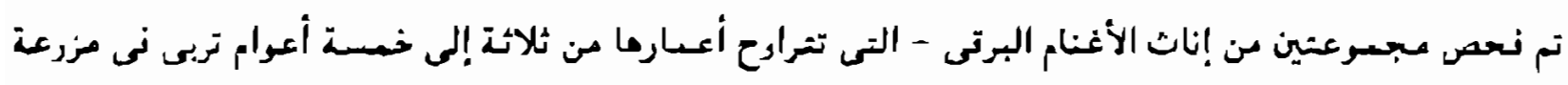

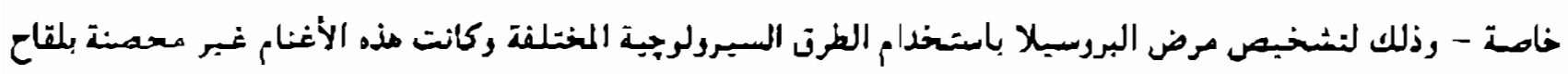

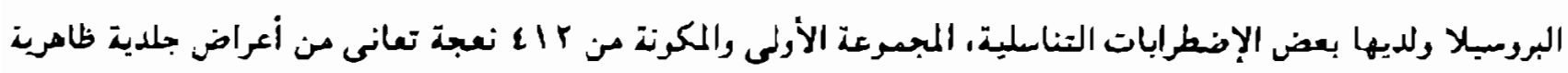

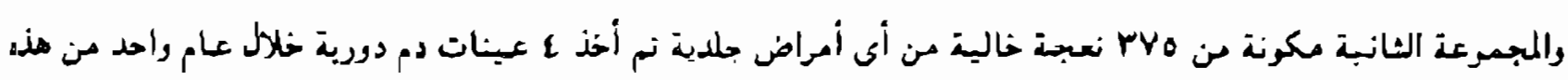

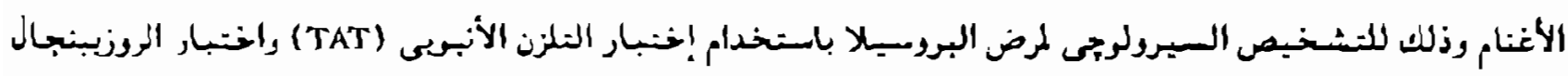
(Rlvanol-T) (TRPT)

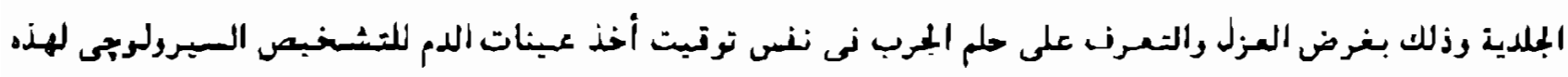

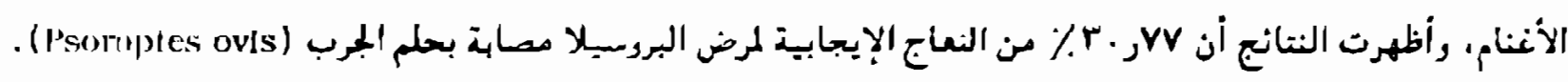
وتد تم كذلك إستـدأم خنازير غينيا نى دراسة الدر رالمتهل الذى يككن أن تسبب الإمابة بهلم المرب كعامل سـاعد

$$
\text { للإمسابة برض البروسيكا. }
$$

رتد تم أيضاح دراسة مقارنة تأثير الإصابة بسلم الجرب على مسترى الأبسام الناعية للبروسيلا فى كلا المجسرعنين. تم علاج الإهابة بالجرب نى هذه الأغنام بعد كل فحص باستخدام العلاجاث المتحصهة المنتلنت. 